\title{
Rhododendrons: A major resource of fuelwood in high altitude region of Arunachal Himalaya, India
}

\author{
ASHISH PAUL ${ }^{1, \vartheta}$, PIJUSH KUMAR DUTTA ${ }^{2}$, MOHAMED LATIF KHAN ${ }^{3}$, ASHESH KUMAR DAS ${ }^{4}$ \\ ${ }^{1}$ Department of Forestry, North Eastern Regional Institute of Science and Technology (Deemed to be University), Nirjuli - 791109, Arunachal Pradesh, \\ India. Tel.: +91-9862035885, `email: ashishpaul1@gmail.com \\ ${ }^{2}$ WWF-India, Game Village, Block A16 (103), Vasistha, Guwahati - 781029, Assam, India. \\ ${ }^{3}$ Department of Botany, Dr. Hari Singh Gour Central University, Sagar - 470003, Madhya Pradesh, India. \\ ${ }^{4}$ Department of Ecology and Environmental Science, Assam University, Silchar - 788011, Assam, India.
}

Manuscript received: 15 July 2019. Revision accepted: 23 August 2019.

\begin{abstract}
Paul A, Dutta PK, Khan ML, Das AK. 2019. Rhododendrons: A major resource of fuelwood in high altitude region of Arunachal Himalaya, India. Biodiversitas 20: 2628-2635. This study highlights rhododendrons consumption for fuelwood in Tawang district of Arunachal Pradesh. Rhododendron spp. contributed the highest (60\% and 58\%), Quercus spp. (33\% and 40\%) while Alnus species (7\% and 2\%) of the total fuelwood consumption in villages between 1800-2100 m and 2100-2400 m altitude, respectively. Consumption was recorded highest $(3.45 \mathrm{~kg} /$ capita/day) in villages between $2100-2400 \mathrm{~m}$ than $1800-2100 \mathrm{~m}$ altitude (3.24 $\mathrm{kg} /$ capita/day). Fuelwood consumption was not significantly varied with altitudes $(\mathrm{U}=364, p=0.864)$. However, it was significantly different among species at altitude $1800-2100 \mathrm{~m}(\mathrm{~F}=6.205, p<0.05)$ and $2100-2400 \mathrm{~m}\left(\chi^{2}=31.319, p<0.001\right)$. Irrespective of altitude, consumption was significantly different among the species $\left(\chi^{2}=41.289, p<0.001\right)$. Rhododendron arboreum and Rhododendron thomsonii with a mean rank of 47.35 and 49.88, respectively, were the most used fuelwood, followed by Quercus griffithii (33.08), Quercus sp. (26.04) and Alnus sp. (8.65). The remote villages, mostly use fuelwood for boiling, cooking and space heating. Intensive consumption pressure will lead to habitat degradation and mount fuelwood crisis in coming years. The present pilot study could be a basis to develop suitable conservation and management of energy resources, particularly the rhododendrons.
\end{abstract}

Keywords: Conservation, Eastern Himalaya, forest management, fuelwood, Rhododendron, unsustainable extraction

\section{INTRODUCTION}

The rural people of the world mostly depended on fuelwood for energy in their day to day domestic purposes. The majority of the rural population hinge on fuelwood, charcoal, crop residues, rice husks, cow dung, etc. to meet up the energy requirements. In many developing countries, fuelwood from the forested areas is providing essential domestic energy to the rural population (Cecelski et al. 1979). In most parts of the world, fuelwood is the key basis of energy in cooking and heating (FAO 2010). Over eighty percent of people around the world are using firewood and charcoal for energy. Population growth has influenced the increase in total fuelwood consumption (OECD/IEA 2010). The increase in demand of consumption has headed to more pressure on natural resources of the world (Tilman et al. 2001; Arrow et al. 2004; Imhoff et al. 2004; Godfray et al. 2010; Liu et al. 2010; Zhen et al. 2011). In many developing countries of the world, fuelwood is the chief source of energy (Kennes et al. 1984; Maikhuri 1991; Hosier and Kipondya 1993; Bhatt et al. 1994; Tabuti et al. 2003; Bhatt and Sachan 2004a, b; Chen et al. 2006; Rawat et al. 2009; Khuman et al. 2011; Pandey and Chaubal 2011; Adkins et al. 2012; San et al. 2012; Rehnus et al. 2013; Ranjitkar et al. 2014). In rural households of the mountainous region of the Himalaya, fuelwood is the foremost source of energy for cooking, space heating and boiling of water (Rijal 1999). Thus, subsistence mainly depends upon resources, which are derived from the natural woodlands (Chettri and Sharma 2006). Because of which, species richness, structure, productivity, and renewal of many high quality and preferred species are declining (Sundriyal et al. 1994; Sundriyal and Sharma 1996; Chettri et al. 2002). Further, high demand species threatens due to overexploitation and also could change the forest structure and composition (Ndangalasi et al. 2007) and at the contiguous level, different approaches of regional agricultural extension, extraction of wood and infrastructure set-up causing deforestation (Geist and Lambin 2002). According to National Sample Survey Office (2012), over 70\% of the Indian people are living in countryside and $76.3 \%$ of the households continued to be contingent on fuelwood for their daily energy needs like boiling, cooking, etc. In the mountainous region of India fuelwood is the prime energy source which supplying the most of the energy for food preparation. People of northeastern states of India also mostly depend on woodlands for fuelwood as the chief energy source (Ramakrishnan 1987) and 90\% inhabitants of this region use biomass as the foremost energy (Bhatt and Sachan 2004a). Moreover, owing to poor socio-economic conditions commercial fuel is out of reach to the rural residents.

Northeastern states of India is well known for its wide range of altitudes and climatic conditions which created a suitable habitat for survival of many plant and animal 
species of ecological and economic significance. The state Arunachal Pradesh is the largest among the northeast region of India has $80.93 \%$ forest and tree cover (FSI 2017) which supports very rich floral and faunal diversity. Arunachal Himalaya contributed approximately fifty percent of the blooming plant species of India (Rao and Hajra 1986). Nearly 34\% geographic area of the state is under temperate forests (Shukla et al. 1994) which harbors varieties of aromatic, medicinal, ethnobotanical, economic and commercially important plant species. The state is a house of many tribes having distinctive culture, custom, and beliefs who are mostly dependent on natural resources. The tribal communities of Arunachal Himalaya mainly dependent on forests and forest products for daily uses like food, fodder, timber, fuel, medicine, etc. Thus, forests are playing a substantial part in socio-cultural and traditional aspects of bucolic people.

Rhododendron L. is the largest genus under the family Ericaceae having over 1000 species distributed throughout Asia, Europe, North America and Australia (Chamberlain et al. 1996; Fang et al. 2005; Gibbs et al. 2011). The genus ranges from tiny mat-like $(2.5 \mathrm{~cm})$ to giant trees up to $40 \mathrm{~m}$ height comprising evergreen, semi-deciduous or deciduous species (Hora 1981; Mao et al. 2017) and grow well in loose, open, well-aerated, acidic soil (Ross 1998; de Milleville 2002). One hundred thirty two taxa (80 species, 25 subspecies and 27 varieties) has been reported from India, out of which 119 taxa (74 species, 21 subspecies and 24 varieties) distributed in Arunachal Pradesh (Mao et al. 2017) with ecological and economic significance. The habitat of rhododendrons ranges from subtropical forests $(800 \mathrm{~m})$ to alpine scrubs $(6500 \mathrm{~m})$ with terrestrial and epiphytic in nature, characterized by variation in morphological features among the species (Mao et al. 2017). Rhododendron act as keystone species in Western Arunachal Pradesh having rich diversity and maintaining the ecological balance in the high altitude ecosystem (Paul et al. 2005; Paul 2008, Paul et al. 2016). Forty seven Rhododendron taxa have been recorded from Tawang and West Kameng district of Arunachal Pradesh, having aesthetic and sacred values with ethnic uses (Paul et al. 2010a, b). Rhododendrons are preferred group of plant species for fuelwood in the Eastern Himalayan Region. Fuelwood is the prime source of energy for domestic purposes in the higher altitude region of Western Arunachal Pradesh. Most of the people living in rural and remote areas, where fuelwood is the key energy source for cooking, boiling and space heating. The principal intents of the present study are (i) to find out the main bull's eye and desired tree species being used by the residents for fuelwood and (ii) to assess the consumption rate of rhododendrons for fuelwood.

\section{MATERIALS AND METHODS}

\section{Study area}

The study area is located in Tawang district of Arunachal Pradesh, which lies between $27^{\circ} 25^{\prime}$ to $27^{\circ} 52^{\prime}$ $\mathrm{N}$ latitude and $91^{\circ} 16^{\prime}$ to $91^{\circ} 59^{\prime} \mathrm{E}$ longitude. The total geographical area of the district is $2,172 \mathrm{~km}^{2}$, which is $2.59 \%$ of the total geographical area of the state. The topography of the district is hilly, mountainous with varying altitude. The total forest cover of the district is $1,177 \mathrm{~km}^{2}$ i.e., $54.19 \%$ of the total geographical area, categorized into very dense forest $341 \mathrm{~km}^{2}$, moderately dense forest $448 \mathrm{~km}^{2}$ and open forest $388 \mathrm{~km}^{2}$ (FSI 2017). The region received high rainfall with maximum rainfall occurring during June-August. The monthly average rainfall ranged from $4 \mathrm{~mm}$ to $500 \mathrm{~mm}$ while mean minimum and maximum temperature remains (-) $2.5^{\circ} \mathrm{C}$ and $25.5^{\circ} \mathrm{C}$, respectively. Tawang Chu and Nyamjang Chu are the main rivers of the district. With the variations in climatic conditions, physiographies and geographical position, the forest of the district is mainly classified into temperate, subalpine and alpine forests.

Monpa is the peace-loving and a main predominant community inhibiting in the Tawang district of Arunachal Pradesh. They belong to the Mongoloid stock and follow Buddhism (Anonymous 2005). They maintain a close relationship with nature and dependent on forests and other natural resources having a rich indigenous knowledge system (IKS) which is playing a substantial role in their lifestyle. The total population of the district is 49,977 with density of 23 persons per $\mathrm{km}^{2}$ (http://www.censusindia.gov.in). Farming and animal husbandries are the fundamental livelihood of the community and over $80 \%$ of the inhabitants dependent on cultivation (Anonymous 2005).

\section{Methods}

In the present study, a total of 250 households from thirteen different villages were surveyed. Villages were broadly categorized into two groups based on the altitudinal location, i.e., $6000-7000 \mathrm{ft}$ (1800-2100 m asl) and $7000-8000 \mathrm{ft}$ (2100-2400 m asl) altitude. And also to examine whether altitude has impact on species and fuelwood consumption pattern. The information was gathered through field observations and interviewing the head of each household of the villages with the help of a structured questionnaire. The most preferred fuelwood tree species were listed either through conversations or field observations. The assessment of fuelwood was done by first assessing the total fuelwood requirement of each household surveyed and then calculating the percent consumption of rhododendrons from the preferred tree species. The amount of fuelwood consumption was assessed following weight survey method for a period of 24 hours (Mitchell 1979; Bhatt et al. 1994). The landholding size, family members, income sources, animal holdings, etc. were not considered in the present study. Besides, shops, hotels, and offices were also not accounted. The total geographical area occupied by the villages, annual fuelwood consumption, and seasonal variation was not estimated. Statistical analysis was done using MS-Excel and SPSS (Version 22) and interpreted following Zar (2014). Shapiro-Wilk test was conducted to determine the data normality. One way ANOVA or Kruskal-Wallis test was performed to compare the variables within the species at each altitude based on their normality. To compare the 
variables between the two altitudes either t-test or MannWhitney U test was performed based on their normality.

\section{RESULTS AND DISCUSSION}

\section{Source and preferred fuelwood tree species}

The present study reveals that tree species like Alnus sp. (Mosheng), Quercus griffithii (Paisheng), Quercus sp. (Ketsheng), Rhododendron arboreum (Udongsheng) and Rhododendron thomsonii (Tamasheng) were mainly used as fuelwood by the local villagers. Among the recorded tree species, Rhododendron spp. contributed highest $(60 \%$ and $58 \%$ ) followed by Quercus spp. (33\% and 40\%) and lowest by Alnus sp. (7\% and $2 \%$ ) of the total fuelwood intake in the villages between $6000-7000 \mathrm{ft}(1800-2100 \mathrm{~m}$ asl) and $7000-8000 \mathrm{ft}(2100-2400 \mathrm{~m}$ asl) altitude, respectively (Figure 1). Highest fuelwood consumption (3.45 $\mathrm{kg} /$ capita/day) was recorded in the villages between 7000 $8000 \mathrm{ft}(2100-2400 \mathrm{~m}$ asl $)$ altitude, which is slightly higher (3.24 kg/capita/day) than the villages between $6000-7000 \mathrm{ft}$ (1800-2100 m asl) altitude (Figure 2). The Mann-Whitney $\mathrm{U}$ test showed that mean values of fuelwood consumption were not significantly different from the altitudes $(\mathrm{U}=364$, $p=0.864)$. However, one way ANOVA exhibited that mean values of fuelwood consumption were significantly different within the species at altitude 1800-2100 (F = $6.205, p<0.05)$. Kruskal-Wallis test revealed significant variance in fuelwood consumption within the species $\left(\chi^{2}=\right.$ $31.319, p<0.001)$ at $2100-2400 \mathrm{~m}$ altitude. Irrespective of altitude, the species consumption pattern as fuelwood was significantly different among the species $\left(\chi^{2}=41.289, p<\right.$ 0.001). Rhododendron arboreum and Rhododendron thomsonii with mean rank fuelwood consumption of 47.35 and 49.88 , respectively, were the two species mostly used by the indigenous people as fuelwood followed by Quercus griffithii (33.08), Quercus sp. (26.04) and Alnus sp. (8.65).

\section{Major uses of fuelwood}

The local people of remote villages are mainly dependent on forest resources for fuelwood since there are no other alternative sources of energy. Most of the fuelwood found to be used for cooking, boiling and space heating in this high altitude region of the state (Figure 3.AB). Besides these, other activities like traditional beverages are also prepared using fuelwood. Moreover, rhododendrons are most preferred firewood species as it burns even under wet conditions. Field observation, as well as assessment of household survey, exhibited that rhododendrons are most extensively harvested fuelwood species and stored in each household.

\section{Impacts on rhododendrons}

The field observations, as well as interactions with the local people, revealed that rhododendrons are mostly extracted from the forest for the fuelwood other than the traditional uses. The decline of nearby forest areas and less availability of other fuelwood species leads to the maximum pressure on rhododendrons. This is leading to the low population and habitat degradation of rhododendrons and affecting the regeneration, growth and survival in this fragile high altitude region of Eastern Himalaya (Figure 4.A-B). Field observations indicated slow growth, very poor seedling density under the canopy and intensive extraction threatens the habitat of rhododendrons. Regeneration from cut stumps through sprouting is also very poorly observed.

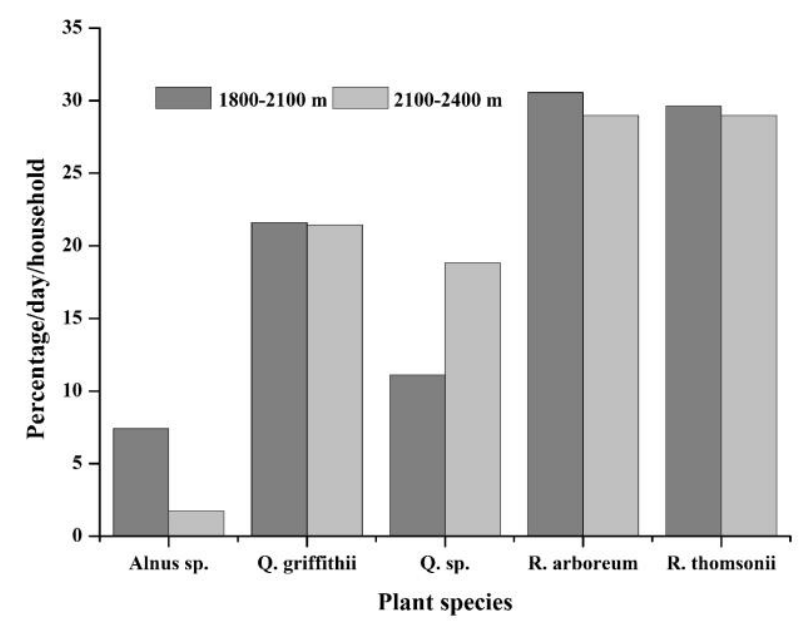

Figure 1. Fuelwood consumption pattern (percentage/day/ household) in the villages at two different altitudinal gradients at Tawang district of Arunachal Pradesh, India

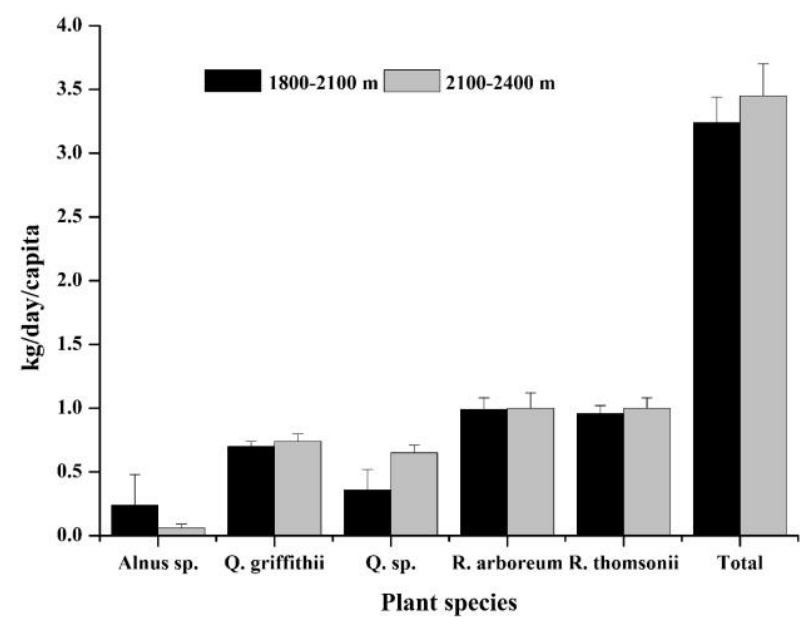

Figure 2. Fuelwood consumption pattern (kg/day/capita) in the villages at two different altitudinal gradients at Tawang district of Arunachal Pradesh, India 




Figure 3. Rhododendrons, the preferred fuelwood of local inhabitants in Western Arunachal Landscape. A. Stockpile of rhododendrons kept beside the house, B. Tin made frame (bukari) used for burning fuelwood on the floor for boiling/cooking and keeping dwellings warm in chilly winter

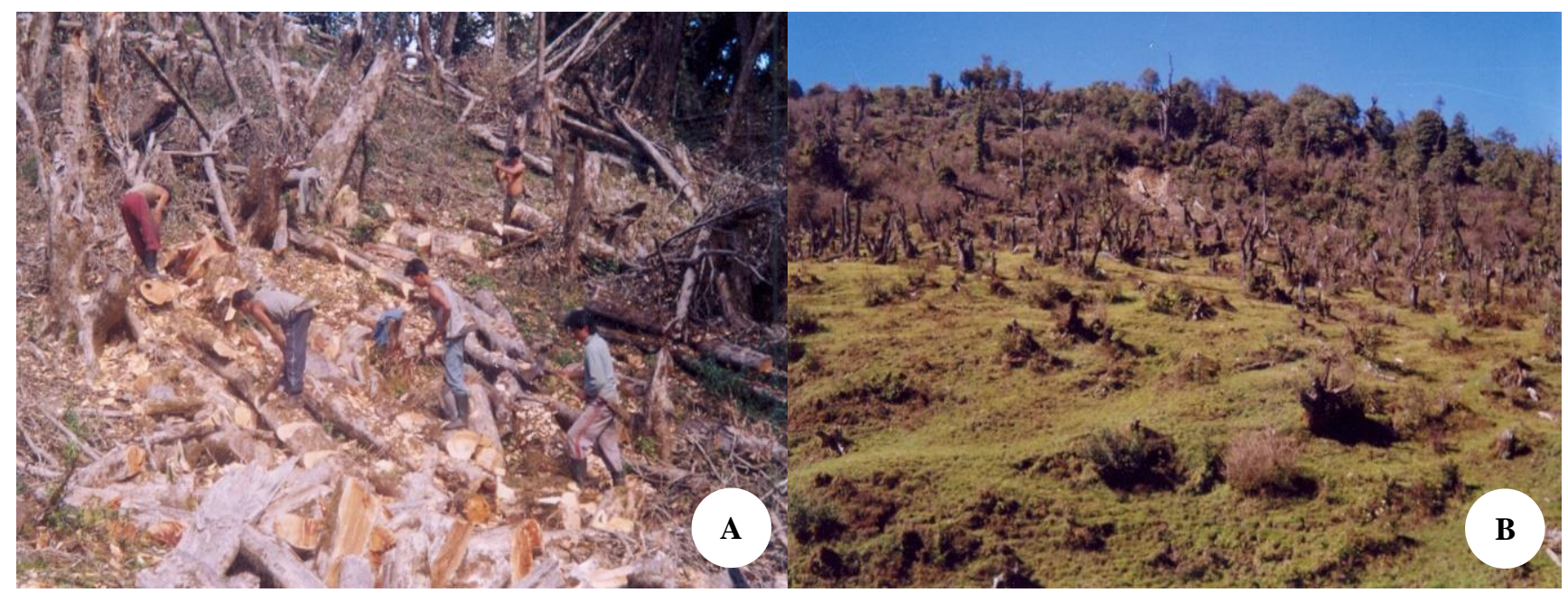

Figure 4. Extraction of rhododendrons for fuelwood for domestic purposes. A. Harvesting of Rhododendron arboreum, B. Degraded Rhododendron forest

\section{Discussion}

The present study observed that people are mainly depended on forests for fuelwood for daily uses. Commercial fuels, like, LPG, electric heater, kerosene, etc. are beyond the reach to the local inhabitants because of poor socioeconomic conditions. Conversely, most of the villages are located in very remote areas, far from market, government run LPG and kerosene outlet. In addition, no suitable alternate resources for space heating other than fuelwood is available in the study area. This study indicates, among the five tree species, Rhododendron spp. contributed the highest percentage of fuelwood consumption in both the elevation because of less availability of other tree species also advantages of being able to burn without drying. The local resident outlined that the consumption of Alnus sp. was lowest among the species mainly because of its poor calorific value. Conversely, utilization of Quercus spp. as fuelwood is low compared to Rhododendron species. The Quercus forest specifically for the collection of leaves for mulching in the agricultural fields traditionally is individually owned and maintained. Cutting of live Quercus trees is strictly banned, although having very good fuelwood quality. However, Quercus trees available outside such forest patches are collected for fuelwood. On the contrary, no restriction has been imposed on the extraction of rhododendrons for fuelwood by the 
village council. Although, awareness of community forest management has been initiated by WWF to conserve the forest resources, including rhododendrons to boost the economy of the local people and also to promote ecotourism. However, this is in very initial stage. Ranjitkar et al. (2014) reported that Rhododendron arboreum contributed 118.02 to $147.53 \times 10^{3} \mathrm{~kg}(20-25 \%)$ of the total fuelwood consumption in Eastern Nepal. Many authors have also reported the utilization of Alnus sp., Quercus spp. and Rhododendron spp. for fuelwood in the higher elevational regions (Chettri and Sharma 2009; Singh et al. 2010). Based on the availability and quality, the local communities from their old aged tradition select wide varieties woodland resources for fuelwood, forage, and wood (Purohit and Nautiyal 1987; Rai et al. 2002). Most of the forests are under community control in the study area, no specific forest area has been restricted for fuelwood extraction except sacred groves. Whereas, $60.38 \%$ of the state's forest area (FSI 2015) belonged to communities known as Unclassed State Forest (USF) and has no control by the Forest Department. However, no traditional practices for protection or afforestation of rhododendrons have been initiated. Protected area network like sanctuary and reserve forest have not been instigated except Rhododendron Park at Tawang, declared by the Forest Department, Government of Arunachal Pradesh in 2018.

The present rate of fuelwood consumption is found to be greater than the reported consumption by the rural and tribal communities of western Himalayas $\left(1.49 \mathrm{~kg}^{-1}\right.$ capita ${ }^{1}$ day $^{-1}$ ) (Bhatt et al. 1994); Nepal (1.23 kg capita $^{-1}$ day $^{-1}$ ) (Mahat et al. 1987). Conversely, the consumption of fuelwood is lower than the stated fuelwood consumption value $\left(10.4 \mathrm{~kg}_{\text {capita }}^{-1} \mathrm{day}^{-1}\right)$ by the Nishi community of Arunachal Pradesh (Maikhuri 1991); Eastern Nepal (5.9 kg capita $^{-1}$ day $^{-1}$ ) (Ranjitkar et al. 2014); Khasi (5.81 kg capita${ }^{1}$ day $\left.^{-1}\right)$, Garo $\left(5.32 \mathrm{~kg}\right.$ capita $^{-1}$ day $^{-1}$ ) and Jaintia $(3.90 \mathrm{~kg}$ capita $^{-1}$ day $^{-1}$ ) community of Meghalaya (Bhatt and Sachan 2004a). Moreover, Rawat et al. (2009) reported fuelwood intake of $4.32 \mathrm{~kg}$ capita $^{-1} \mathrm{day}^{-1}$ at Khoksar during winter, $2.25 \mathrm{~kg}$ capita $^{-1} \mathrm{day}^{-1}$ in autumn while $1.38 \mathrm{~kg} \mathrm{capita}^{-1} \mathrm{day}^{-1}$ in summer in the cold desert of the Lahaul valley, Himachal Pradesh. Besides, Bhatt and Sachan (2004b) recorded fuelwood consumption 2.80, 2.00, 1.42, 1.10 and $1.07 \mathrm{~kg}_{\text {capita }}{ }^{-1} \mathrm{day}^{-1}$, respectively above 2000,1500 2000, 1000-1500, 500-1000 and below $500 \mathrm{~m}$ altitudes along the altitudinal gradient in Garhwal Himalaya, Uttarakhand. However, it was 2.0-3.0 folds higher in winter than summer. Further, Kumar and Sharma (2009) recorded highest fuelwood consumption in Ganga Bhogpur $(2.52 \mathrm{~kg}$ capita $^{-1}$ day $^{-1}$ ) in the tropical region and lowest in Ghargoan $\left(1.63 \mathrm{~kg} \mathrm{capita}^{-1} \mathrm{day}^{-1}\right)$ in the subtropical region in Garhwal Himalaya. Whereas, in Fakot micro watershed in Garhwal district of Uttarakhand, India, fuelwood intake was recorded within the range of $455-2388 \mathrm{gm} /$ person/day (Khuman et al. 2011). Present fuelwood consumption was not significantly varied with the altitudes. However, within the species, a significant variation was found at the respective altitudes. Among the species, the fuelwood consumption pattern was significantly different. Present study area, location, climatic condition, edaphic factors, species composition and the ethnic community, etc. are entirely different compared to the study carried out by Maikhuri (1991) in other parts of Arunachal Pradesh. Moreover, the area selected for the present study is inhibited by Monpa, the predominant community in the Tawang district of Arunachal Pradesh. In addition, our study area was located in temperate region compared to Maikhuri (1991) which was in tropical region (200 m asl) at Balijan nearby the capital city of Itanagar of the state and thus the species availability and purpose of uses are different. Mislimshoeva et al. (2014) reported that elevation, household size and heating period in winter have a positive impact on fuelwood intake in the villages while education level and power supply from the city has a negative influence of their study in rocky, high mountains Western Pamirs, Tajikistan.

The local inhabitants reported that because of straight bole, easy to break and quality to burn even undried conditions, most of the people inhabiting the temperate, sub-alpine and alpine regions used Rhododendron species as fuelwood and are most preferred species. Singh et al. (2003) also reported that rhododendrons are most preferred firewood species as it contains polyphenols and flavonoids because of which it burns even at wet conditions. While, Singh et al. (2010) reported that Alnus nepalensis, Quercus floribunda, Quercus glauca, Quercus leucotrichophora, Quercus semecarpifolia, Rhododendron arboreum, and Rhododendron campanulatum have excellent fuelwood quality from Garhwal Himalaya, India. Purohit and Nautiyal (1987) reported that Punica granatum, Sapindus mukorossi, Rhododendron arboreum, Quercus spp., Adina cordifolia, Ougeinia dalbergioides and Pyrus pashia were most promising with high Fuelwood Value Index (FVI) among the forty-four Indian mountain tree species. While, Rai et al. (2002) reported that Castanopsis tribuloides, Quercus lineata, and Quercus lamellosa have high FVI values followed by Eurya acuminata and Cinnamomum impressinervium with moderate and Andromeda elliptica and Engelhardtia sp. were ranked lower on the basis of local people ranking system and FVI values. To assess the species, both the FVI value and community preferences should also be taken into consideration for afforestation and management (Rai et al. 2002). Many workers have also reported similar utilization of Rhododendron species in Sikkim Himalaya (Pradhan and Lachungpa 1990; Singh et al. 2003). Similarly, Quercus spp. and Rhododendron spp. were reported to be the utmost enviable fuelwood for the local people of Yuksam-Dzongri hiking flight path in Sikkim Himalaya (Chettri and Sharma 2007). However, Kumar and Sharma (2009) reported Quercus leucotrichophora, Myrica esculenta, and Pyracantha crenulata were most preferred tree species for fuelwood in the temperate region of Garhwal Himalaya. Conversely, Schima wallichii, Castanopsis indica, Dendrocalamus hamiltonii, and Dillenia indica were reported to be preferred tree species used for fuelwood by Nishis, Karbis, Kacharis and Chackmas (Maikhuri 1991). San et al. (2012) reported that about $96 \%$ of sampled households depend on fuelwood for cooking, water boiling, animal feed preparation and cattle protection against 
insects attack in Chumriey Mountain, Kampong Chhnang Province, Cambodia. FAO (2010) reported that fuelwood is the key energy source for cooking and heating in most parts of the globe. There are robust influences of fuelwood extraction and other usages, which have future consequences for both the forest-dependent people and conservationists (Sassen et al. 2015).

This field study exhibited continue rhododendrons extraction for fuelwood might lead to the rapid depletion of rhododendrons population and habitat as well as birds, insects, etc. It has also been observed that seedlings are very rare beneath the canopy while abundant in forest edges or margins. However, very poor seedling to sapling establishment is observed. Moreover, very dawdling growth in terms of height has been observed, which concur with the findings of Jackson (1994) that few millimeters in height during 1-2 years and also low temperature and light intensity under the canopy. Very thick leaf litter layer of rhododendrons was also observed and which threatened the establishment of seedlings under canopy (Schmidt-Vogt 1990). Moreover, rhododendron leaves decompose very slowly (Gulis and Suberkropp 2003) that accumulate the thick litter layer and inhibits seedling establishment (Haruki 1984). Paul et al. (2010 c) reported that cut stump sprouting of rhododendrons is not playing an ample role in natural regeneration where indiscriminate harvesting is continued. In the context, increase of local farming, animal husbandry practices, untenable extraction of fuelwood, etc. have erected the pressure on the habitat and regeneration of many Rhododendron species. Consequently, slow growth, low seedling survival, poor sprout regeneration, and harvesting and overexploiting of species reducing the diversity, density, and biomass in this high mountainous region. This result confirms the outcomes of Salerno et al. (2010) for Abies spectabilis (D. Don) Mirb. in Sagarmatha National Park and Buffer Zone (SNPBZ), Nepal.

\section{Conclusion}

People inhabiting in remote and undulating hilly terrain of Western Arunachal Pradesh are entirely depending on firewood energy. Besides, in recent time increasing demand in commercial for firewood in urban areas, mainly for space heating during winter. Above to its quality in addition to other plant species limited availability; rhododendrons are facing maximum pressure in such areas. As a consequent, the structure, regeneration, growth, and survival of rhododendrons have been affected, leading to the forfeiture of life form in addition to degradation of habitat across the fragile high altitude ecosystem. The present trend of unsustainable extraction is alarming and desires to be regulated so as to reduce the depletion of the natural population and crisis of fuelwood in coming years. There is an urgent need to initiate conservation programs to protect this important genus Rhododendron in Arunachal Himalaya, particular in Western Arunachal Pradesh. An alternate source like crop residues, cow dung, biogas, kerosene, etc. should be encouraged for rural domestic energy. Usage of stoves, biogas, LPG, solar heater, solar cooker, etc. through improved technology may also be provided to reduce the energy requirements which in turn reduce the pressure on forest resources. In addition, hydropower generation and electrification of remote villages are very much needed to minimize the pressure on forest wealth including rhododendrons. Therefore, efforts should be made to understand, the better substitute for fuelwood for the rural people by adopting improved energy conversion technologies to reduce the pressure on rhododendrons in particular. Various afforestation programs should be put into practice in this hilly region of the district where people's participation is the foremost one.

Rhododendrons can play a key role in growth of ecotourism in Arunachal Pradesh like Sikkim. About 90\% of the reported taxa of the country is contributed by Arunachal Himalaya, which will raise the economy of the local community and substantial revenues for the state government. The genus Rhododendron has very good potential for horticulture/floriculture and many hybrids have been developed with most attractive flowers. Almost $50 \%$ of the Rhododendron species are under cultivation worldwide for various purposes. The huge amount of revenue can be generated, as done in the western countries through horticulture/floriculture of rhododendrons. The Unclassed State Forest (USF) or community forests may be encouraged for eco-tourism and revenue regeneration. Rhododendron arboreum flowers can be used to prepare squash in this region to generate revenue as it is practicing in Uttarakhand. Although Arunachal Pradesh has the highest geographical area among the northeastern states, however, only $11.68 \%$ of area covers the protected network (http://www.wiienvis.nic.in). Thus, Rhododendron rich areas (Rhododendron Park, established at Tawang by the Forest Department) can be brought under protected area network like Sikkim viz., Shingba and Barsey Rhododendron sanctuaries established by the Sikkim Government, which witnessed of huge tourist influx. Further, Rhododendron bonsai/ornamental plants/avenue tree for promotion of tourism in the state will uplift the community economy.

\section{ACKNOWLEDGEMENTS}

The financial assistance provided by the Council of Scientific and Industrial Research (CSIR), New Delhi is thankfully acknowledged. Thanks to WWF-India Secretariat, New Delhi and Officials of Field Office, Arunachal Pradesh for necessary support and cooperation. Authors express earnest thanks to all the local field guides, village headmen and villagers for help and cooperation during the fieldwork. Thanks to Mr. Bijit Basumatary and the army personnel for their help and support during the field study. Authors are thankful to all, those who extended their cooperation during the field study. We are also thankful to Principal Chief Conservator of Forest, Department of Environment and Forests, Government of Arunachal Pradesh for allowing us to work in forest areas of the state. Thanks to Dr. Boni Amin Laskar for his help in preparing the manuscript. 


\section{REFERENCES}

Adkins E, Oppelstrup K, Modi V. 2012. Rural household energy consumption in the millennium villages in Sub-Saharan Africa. Energy Sustain Dev 16 (3): 249-259.

Anonymous. 2005. Statistical abstract of Arunachal Pradesh. Directorate of Economics and Statistics. Government of Arunachal Pradesh.

Arrow K, Dasgupta P, Goulder L, Daily G, Ehrlich P, Heal G, Levin S, Maler KG, Schneider S, Starrett D, Walker B. 2004. Are we consuming too much? J Econ Perspect 18 (3): 147-172.

Bhatt BP, Negi AK, Todaria, NP. 1994. Fuelwood consumption pattern at different altitudes in Garhwal Himalaya. Energy 19 (4): 465-468.

Bhatt BP, Sachan M. 2004a. Firewood consumption pattern of different tribal communities in Northeast India. Energy Policy 32 (1): 1-6.

Bhatt BP, Sachan M. 2004b. Firewood consumption along an altitudinal gradient in mountain villages of India. Biomass Bioenerg 27 (1): 69 75.

Cecelski E, Dunkerley J, Ramsay W. 1979. Household energy and the poor in the third world. RFF research paper, R-15. Resources for the Future, Washington, DC, USA.

Chamberlain DF, Hyam R, Argent G, Fairweather G, Walter KS. 1996. The Genus Rhododendron: its Classification and Synonymy. Royal Botanic Garden Edinburgh. Edinburgh, United Kingdom.

Chen L, Heerink N, van den Berg M. 2006. Energy consumption in rural China: A household model for three villages in Jiangxi Province. Ecol Econ 58 (2): 407-420.

Chettri N, Sharma E, Deb DC, Sundriyal RC. 2002. Impact of firewood extraction on tree structure, regeneration and woody biomass productivity in a trekking corridor of the Sikkim Himalaya. Mt Res Dev 22 (2): 150-158.

Chettri N, Sharma E. 2006. Assessment of natural resources uses patterns a case study along a trekking corridor of Sikkim Himalaya, India. J Res Energ Dev 3 (1): 21-34.

Chettri N, Sharma E. 2007. Firewood value assessment: A comparison on local preference and wood constituent properties of species from a trekking corridor, West Sikkim, India. Curr Sci 92 (1): 1744-1747.

Chettri N, Sharma E. 2009. A scientific assessment of traditional knowledge on firewood and fodder values in Sikkim, India. For Ecol Manag 257 (10): 2073-2078.

de Milleville R. 2002. The Rhododendrons of Nepal. Himal Books, Katmandu, Nepal.

ENVIS Centre on Wildlife and Protected Areas. 2019. Wildlife Institute of India, Dehradun. Ministry of Environment, Forests and Climate Change, Government of India. http://www.wiienvis.nic.in. [5 August 2019].

Fang M, Fang R, He M, Hu L, Yang H, Chamberlain DF. 2005 Rhododendron Linnaeus. In: Wu CY, Raven PH, Hong DY (eds) Flora of China. Apiaceae through Ericaceae. Vol. 14. Science Press (Beijing), China and Missouri Botanic Garden Press (St. Louis), USA.

FAO. 2010. Criteria and indicators for sustainable woodfuels. FAO Forestry Paper 160. Food and Agriculture Organization of the United Nations, Rome, Italy.

FSI. 2015. State of Forest Report 2015. Forest Survey of India. Ministry of Environment and Forests, Dehradun, India.

FSI. 2017. State of Forest Report 2017. Forest Survey of India. Ministry of Environment and Forests, Dehradun, India.

Geist HJ, Lambin EF. 2002. Proximate causes and underlying driving forces of tropical deforestation. BioScience 52 (2): 143-150.

Gibbs D, Chamberlain D, Argent G. 2011. The Red List of Rhododendrons. Botanic Gardens Conservation International Richmond, United Kingdom.

Godfray HJC, Crute IR, Haddad L, Lawrence D, Muir JF, Nisbett N, Pretty J, Robinson S, Toulmin C, Whiteley R. 2010. The future of the global food system. Phil Trans R Soc B 365 (1554): 2769-2777.

Gulis V, Suberkropp K. 2003. Leaf litter decomposition and microbial activity in nutrient-enriched and unaltered reaches of a headwater stream. Freshw Biol 48 (1): 123-134.

Haruki M. 1984. On the rhododendron forests in Central Nepal. Tethys Res 3: 4e21.

Hora B. 1981. The Oxford Encyclopedia of Trees of the World. Consent Books, Oxford University Press, New York

Hosier RH, Kipondya W. 1993. Urban household energy use in Tanzania: prices, substitutes and poverty. Energy Policy 21 (5): 454-473.
Imhoff ML, Bounoua L, Ricketts T, Loucks C, Harriss R, Lawrence WT. 2004. Global patterns in human consumption of net primary production. Nature 429 (6994): 870-873.

Jackson JK. 1994. Manual of Afforestation in Nepal. Nepal-United Kingdom Forestry Research Project, Forest Research and Survey Centre. $2^{\text {nd }}$ ed. Ministry of Forests and Soil Conservation. Kathmandu, Nepal.

Kennes W, Parikh JK, Stolwijk H. 1984. Energy from biomass by socioeconomic groups - a case study of Bangladesh. Biomass 4 (3): 209234.

Khuman YSC, Pandey R, Rao KS. 2011. Fuelwood consumption patterns in Fakot watershed, Garhwal Himalaya, Uttarakhand. Energy 36 (8): 4769-4776.

Kumar M, Sharma CM. 2009. Fuelwood consumption pattern at different altitudes in rural areas of Garhwal Himalaya. Biomass Bioenerg 33 (10): 1413-1418.

Liu S, Costanza R, Farber S, Troy A. 2010. Valuing ecosystem services. Theory, practice, and the need for a transdisciplinary synthesis. Ann NY Acad Sci 1185 (1): 54-78

Mahat TBS, Griffin DM, Shepherd KR. 1987. Human impact on some forests of the middle hills of Nepal. Part 4: A detailed study in southeast Sindhu Palchok and northeast Kabhre Palanchok. Mt Res Dev 7 (2): 111-134.

Maikhuri RK. 1991. Fuelwood consumption pattern of different tribal communities living in Arunachal Pradesh in North-East India. Bioresour Technol 35 (3): 291-296.

Mao AA, Dash S, Singh P. 2017. Rhododendrons of North East India. A Pictorial Handbook. $1^{\text {st }}$ ed. Botanical Survey of India. Kolkata, India.

Mislimshoeva B, Hable R, Fezakov M, Samimi C, Abdulnazarov A, Koellner T. 2014. Factors influencing households' firewood consumption in the Western Pamirs, Tajikistan. Mt Res Dev 34 (2): 147-156.

Mitchell R. 1979. The analysis of Indian agro-ecosystems. Interprint, New Delhi, India.

Ndangalasi HJ, Bitariho R, Dovie DBK. 2007. Harvesting of non-timber forest products and implications for conservation in two montane forests of East Africa. Biol Conserv 134 (2): 242-250.

NSSO. 2012. National Sample Survey Office. Energy sources of Indian households for cooking and lighting. Report No.542 (66/1.0/4). Ministry of Statistics and Programme Implementation. Government of India.

OECD/IEA. 2010. Energy and Poverty, Special early excerpt from the World Energy Outlook 2010 for the UN General Assembly on the Millennium Development Goals. Paris, France: International Energy Agency.

Office of the Registrar General and Census Commissioner, India. 2019. Ministry of Home Affairs, Government of India. http://www.censusindia.gov.in. [5 August 2019].

Pandey VL, Chaubal A. 2011. Comprehending household cooking energy choice in rural India. Biomass Bioenerg 35 (11): 4724-4731.

Paul A, Khan ML, Arunachalam A, Arunachalam K. 2005. Biodiversity and conservation of rhododendrons in Arunachal Pradesh in the IndoBurma biodiversity hotspot. Curr Sci 89 (4): 623-634.

Paul A, Khan ML, Das AK, Dutta PK. 2010a. Diversity and distribution of rhododendrons in Arunachal Himalaya, India. J Am Rhodo Soc 64 (4): 200-205

Paul A, Khan ML, Das AK. 2010b. Utilization of rhododendrons by Monpas in western Arunachal Pradesh, India. J Am Rhodo Soc 64 (2): 81-84.

Paul A, Khan ML, Das AK. 2010c. Effect of stump girth and height on resprouting of Rhododendron arboreum following disturbance in temperate mixed broad-leaved forest of Arunachal Pradesh, India. J For Res 21 (4): 433-438.

Paul A, Khan ML, Das AK. 2016. Western Arunachal Pradesh, centre of rhododendrons: needs urgent conservation. In: Upadhaya K (ed) Biodiversity and Environmental Conservation. $1^{\text {st }}$ ed. Discovery Publishing House Private Limited. New Delhi, India.

Paul A. 2008. Studies on diversity and regeneration ecology of rhododendrons in Arunachal Pradesh. [Dissertation]. Assam University, Silchar, Assam, India.

Pradhan UC, Lachungpa ST. 1990. Sikkim-Himalayan Rhododendrons. Primulaceae Books, Darjeeling, West Bengal, India.

Purohit AN, Nautiyal AR. 1987. Fuelwood value index of Indian mountain tree species. Intl Tree Crops J 4 (2-3): 177-182. 
Rai YK, Chettri N, Sharma E. 2002. Fuelwood value index of woody tree species from forests of Mamlay Watershed in South Sikkim, India For Trees Livelihoods 12 (3): 209-219.

Ramakrishnan PS. 1987. Energy flows and shifting cultivation. In Kumar VTM, Ahuja DR (eds) Rural Energy Planning for the Indian Himalayas (pp. 247-276). Wiley Eastern, New Delhi, India.

Ranjitkar S, Sujakhu NM, Jati R, Xu J, Schmidt-Vogt D. 2014. Yield and household consumption of Rhododendron arboreum as a fuelwood species in Eastern Nepal. Biomass Bioenerg 61: 245-253.

Rao RR, Hajra PK. 1986. Floristic diversity of the eastern Himalaya - in a conservation perspective. Proc Indian Acad Sci (Animal Science/Plant Science) Suppl: 103-125.

Rawat YS, Vishvakarma SCR, Todaria NP. 2009. Fuel wood consumption pattern of tribal communities in cold desert of the Lahaul valley, North-Western Himalaya, India. Biomass Bioenerg 33 (11): 1547 1557.

Rehnus M, Nazarek A, Mamadzhanov D, Venglovsky BI, Sorg JP. 2013 High demand for firewood leads to overuse of walnut-fruit forests in Kyrgyzstan. J For Res 24 (4): 797-800.

Rijal K. 1999. Energy use in mountain areas: Trends and patterns in China, India, Nepal and Pakistan. International Centre for Integrated Mountain Development (ICIMOD), Kathmandu, Nepal.

Ross G. 1998. Botanica. The illustrated A-Z of over 10000 garden plant for Australian gardens and how to cultivate them. $2^{\text {nd }}$ ed. Random House, Australia.

Salerno F, Viviano G, Thakuri S, Flury B, Maskey RK, Khanal SN, Bhuju D, Carrer M, Bhochhibhoya S, Melis MT, Giannino F, Staiano A Carteni F, Mazzoleni S, Cogo A, Sapkota A, Shrestha S, Pandey RK, and Manfredi EC. 2010. Energy, forest, and indoor air pollution models for Sagarmatha National Park and buffer zone, Nepal. Mt Res Dev 30 (2): 113-126.

San V, Spoann V, Ly D, and Chheng NV. 2012. Fuelwood consumption patterns in Chumriey Mountain, Kampong Chhnang Province, Cambodia. Energy 44 (1): 335-346.
Sassen M, Sheil D, Giller KE. 2015. Fuelwood collection and its impacts on a protected tropical mountain forest in Uganda. For Ecol Manag 354: 56-67.

Schmidt-Vogt D. 1990. High altitude forests in the Jugal Himal (eastern central Nepal): Forest types and human impact. Stuttgart, Germany: Franz Steiner Verlag.

Shukla GP, Rao K, Haridasan K. 1994. Taxus baccata in Arunachal Pradesh. Arunachal Forest News 12 (1): 1-7.

Singh G, Rawat GS, Verma D. 2010. Comparative study of fuelwood consumption by villagers and seasonal "Dhaba owners"' in the tourist affected regions of Garhwal Himalaya, India. Energy Policy 38 (4): 1895-1899.

Singh KK, Kumar S, Rai LK, Krishna AP. 2003. Rhododendrons conservation in the Sikkim Himalaya. Curr Sci 85 (5): 602-606.

Sundriyal RC, Sharma E, Rai LK, Rai SC. 1994. Tree structure, regeneration and woody biomass removal in a sub-tropical forest of Mamlay watershed in the Sikkim Himalaya. Vegetatio 113 (1): 53-63.

Sundriyal RC, Sharma E. 1996. Anthropogenic pressure on tree structure and biomass in the temperate forest of Mamlay watershed in Sikkim. For Ecol Manag 81 (1-3): 113-134.

Tabuti JRS, Dhillion SS, Lye KA. 2003. Firewood use in Bulamogi County, Uganda: species selection, harvesting and consumption patterns. Biomass Bioenerg 25 (6): 581-596.

Tilman D, Fargione J, Wolff B, D'Antonio C, Dobson A, Howarth R, Schindler D, Schlesinger WH, Simberloff D, and Swackhamer D. 2001. Forecasting agriculturally driven global environmental change. Science 292 (5515): 281-284

Zar JH. 2014. Biostatistical Analysis. $5^{\text {th }}$ ed. Pearson Education, Harlow, England.

Zhen L, Liu X, Wei Y, Yang L, Long X, Du B, Li F, Cao X. 2011. Consumption of ecosystem services: a conceptual framework and case study in Jinghe watershed. J Resour Ecol 2 (4): 298-306. 